${ }^{4}$ Hakama M, Pukkala E. Selective screening for cervical cancer. Experience of the Finnish mass screening system. Brf Prev Soc Med 1977;31:23844.

${ }^{5}$ Hakama M, Pukkala E, Saastamoinen P. Selective screening: theory and practice based on high-risk groups of cervical cancer. $\mathcal{f}$ Epidemiol Community Health $1979 ; 33: 257-61$.

${ }^{6} \mathrm{Knox}$ EG. Ages and frequencies for cervical cancer screening. Br $\mathcal{f}$ Cancer $1976 ; 34: 444-52$.

7 Spriggs AI, Husain OAN. Cervical smears. Br Med $\mathcal{F} 1977$;i :1516-8.

\section{Inhibitors of angiotensin I converting enzyme for treating hypertension}

The available antihypertensive agents are not so consistently potent or free from side effects as to preclude interest in a new type of drug. Two compounds recently studied ${ }^{\mathbf{2}}$ are com- $^{2}$ petitive inhibitors of the enzyme responsible for converting the largely inactive decapeptide angiotensin I to the vasoactive octapeptide angiotensin II. One of these, the nonapeptide teprotide, is of limited clinical use because it has to be given intravenously; but the proline derivative captopril is active by mouth and can be given long term. ${ }^{2}{ }^{3}$ Both teprotide ${ }^{4-7}$ and captopril ${ }^{3}$ 8-10 lower plasma concentrations of angiotensin II, and this fall is sustained during prolonged treatment. Aldosterone, largely regulated by angiotensin II, is also lowered. ${ }^{3-5} 9-15$ Concurrently, components of the renin-angiotensin system proximal to the enzyme blockade-renin and angiotensin Iare increased. ${ }^{3-5}$ 7-10

The initial reduction in blood pressure from teprotide or captopril is proportional to the pretreatment plasma activity of renin. ${ }^{15-17}$ While the immediate drop in pressure is closely related to the extent of the fall in plasma angiotensin II this does not necessarily confirm a simple cause-effect mechanism. ${ }^{8}$

If exogenous angiotensin II is infused after administration of teprotide or captopril a higher plasma concentration of angiotensin II has to be attained than before treatment in order to restore the blood pressure to control values. ${ }^{6}{ }^{18}$ Hence there are components of the antihypertensive action in addition to the effect on angiotensin II. Further evidence is provided by the lowering of blood pressure by captopril in sodium-depleted anephric patients, ${ }^{19}$ though the significance of this finding has been disputed. ${ }^{20}$ Converting enzyme is one of the enzymes which metabolise the vasodilator peptide bradykinin, ${ }^{21}$ and hence inhibitors of converting enzyme might in part lower blood pressure by prolonging the survival of bradykinin. Nevertheless, whether or not these drugs do cause a rise in circulating kinins is disputed. ${ }^{4-6} 92223$ None of the reports excludes the possibility of an accumulation of vasodilator kinins in other tissues. Another possible component of the hypotensive effect of captopril is an increase in production of prostaglandins..$^{43}$ Whatever the cause may be, in addition to the initial effect related directly to angiotensin II, the arterial pressure often drops slowly over the first one to three weeks. 8141524

The fall in plasma concentration of aldosterone will promote excretion of sodium, but this is partly countered by a diminution of the natriuresis related to blood pressure and by a reduction in the direct natriuretic action of angiotensin II. ${ }^{11} 14$ An initial loss of sodium has been found by some workers ${ }^{14}$ but not others, ${ }^{17}$ while long-term changes have not been detected in exchangeable sodium. ${ }^{825}$ The serum potassium concentra- tion rises fairly consistently, ${ }^{8} 914$ no doubt reflecting the fall in aldosterone; even in patients with renal impairment, however, dangerous increases ${ }^{26}$ have been rare. Most reports have commented on an absence of reflex tachycardia and of postural hypotension, 312 though both have been described.

Captopril would be expected to control those forms of hypertension associated with high peripheral blood levels of renin (and hence of angiotensin II). Benefit has been seen in hypertension with renin-secreting tumour, ${ }^{27}$ in renal failure with hypertension resistant to haemodialysis, ${ }^{28}$ and in malignant hypertension..$^{32930}$ But captopril can control blood pressure not only in renovascular hypertension with high plasma renin: it is effective also in the preoperative treatment of patients with renal artery stenosis and normal renin. ${ }^{813}$ The pathogenic role of the renin-angiotensin system in such cases remains uncertain $^{3}$; nevertheless, the correction of hypertension with a drug which (among other actions) lowers plasma concentrations of angiotensin II is noteworthy. Even more interesting is the effectiveness of captopril long term in patients with essential hypertension without raised plasma renin. ${ }^{15}$

When a diuretic is given alone as treatment for hypertension plasma concentrations of angiotensin II rise, limiting the hypotensive effect. ${ }^{3132}$ In theory, therefore, there is a good case for combining captopril with diuretic treatment. In practice, this combination has been strikingly effective in patients with refractory hypertension, ${ }^{242933}$ even in the presence of renal impairment; while the fall in aldosterone not only helps to lower the blood pressure but also limits the hypokalaemia induced by the diuretic. ${ }^{933}$

Hitherto, captopril has been given long term in a dose of 150 mg by mouth three times daily; administration might possibly be less frequent. Lower doses have recently been recommended by the manufacturers for patients with renal impairment; how effective these reduced doses will be in suppressing angiotensin II and controlling blood pressure remains to be seen.

A steep initial fall in arterial pressure is to be expected when an inhibitor of converting enzyme is given to a patient with very high plasma activities of renin. ${ }^{311} 16$ In these circumstances serious hypotension has been countered by giving saline ${ }^{1116}$; but this is an imprecise method of regulating blood pressure and may not be safe in patients with heart disease. An alternative approach, which may be of value when earlier treatment with a diuretic was unavoidable, is to give a carefully regulated infusion of angiotensin II after the captopril, so titrating blood pressure up or down as needed. Saline can then be more safely replaced and the patient's condition stabilised under controlled conditions. ${ }^{25}$

Early reports suggested that captopril was relatively free from toxic effects, those most frequently reported being rashes, fever, and myalgia. ${ }^{912} 131617$ With greater experience, however, more frequent and sometimes serious adverse reactions have emerged including disturbance of taste, 81534 aphthous ulcers, ${ }^{35}$ leucopenia, ${ }^{36}{ }^{37}$ serum sickness, ${ }^{38}$ and nephrotic syndrome. ${ }^{3339}$ More recently, renal biopsy specimens from patients taking captopril and who may have neither renal symptoms nor proteinuria have shown immune-complex deposits along the glomerular basement membrane. The implications of these findings remain uncertain. ${ }^{40}$ GuillainBarré neuropathy has been reported ${ }^{41}$ in a patient taking captopril with cimetidine-a drug which can alter immune responses. ${ }^{42}$

The converting enzyme inhibitors are a new and exciting group of antihypertensive agents with undoubted potency. Captopril is the only one available for oral use but it has proved to have frequent adverse effects, some serious. 
Probably for the present captopril should be reserved for otherwise refractory hypertension, ${ }^{2533}{ }^{34}$ particularly as the vasodilator drug minoxidil has proved an effective alternative in these circumstances. ${ }^{43}$ Less toxic converting enzyme inhibitors nevertheless have great therapeutic potential.

${ }^{1}$ Ondetti AM, Williams NJ, Sabo EF, Pluščec J, Weaver ER, Kocy O. Angiotensin-converting enzyme inhibitors from the venom of Bothrops jararaca. Isolation, elucidation of structure, and synthesis. Biochemistry $1971 ; 10: 4033-9$.

2 Ondetti AM, Rubin B, Cushman DW. Design of specific inhibitors of angiotensin-converting enzyme: new class of orally active antihypertensive agents. Science 1977;196:441-4.

${ }^{3}$ Atkinson AB, Robertson JIS. Captopril in the treatment of clinical hypertension and cardiac failure. Lancet 1979; ;i :836-9.

4 Vinci JM, Horwitz D, Zusman RM, Pisano JJ, Catt KJ, Keiser HR. The effect of converting enzyme inhibition with SQ 20,881 on plasma and urinary kinins, prostaglandin $\mathrm{E}$, and angiotensin II in hypertensive man. Hypertension 1979;1:416-26.

${ }^{5}$ Hulthen L, Hökfelt $B$. The effect of the converting enzyme inhibitor SQ 20,881 on kinins, renin-angiotensin-aldosterone and catecholamines in relation to blood pressure in hypertensive patients. Acta Med Scand 1978;204:497-502.

${ }^{6}$ Swartz SL, Williams GH, Hollenberg NK, Moore TJ, Dluhy RG. Converting enzyme inhibition in essential hypertension: the hypotensive response does not reflect only reduced angiotensin II formation. Hypertension 1979; 1:106-11.

${ }^{7}$ Morton JJ, Semple PF, Ledingham IMcA, et al. Effect of angiotensinconverting enzyme inhibitor (SQ 20,881) on the plasma concentration of angiotensin I, angiotensin II, and arginine vasopressin in the dog during hemorrhagic shock. Circ Res 1977;41:301-8.

${ }^{8}$ Atkinson AB, Brown JJ, Fraser R, et al. Captopril in hypertension with renal artery stenosis and in intractable hypertension; acute and chronic changes in circulating concentrations of renin, angiotensins I and II and aldosterone, and in body composition. Clin Sci 1979;57:139s-43s.

9 Johnston CI, Millar JA, McGrath BP, Matthews PG. Long-term effects of captopril (SQ 14,225) on blood-pressure and hormone levels in essential hypertension. Lancet 1979 ;ii:493-5,6.

${ }^{10}$ Fagard R, Amery A, Lijnen P, Reybrouck T. Haemodynamic effects of captopril in hypertensive patients: comparison with saralasin. Clin Sci $1979 ; 57: 131 \mathrm{~s}-4 \mathrm{~s}$

${ }^{11}$ Atkinson AB, Brown JJ, Davies DL, et al. Hyponatraemic hypertensive syndrome with renal-artery occlusion corrected by captopril. Lancet 1979 ;ii :606-9.

${ }^{12}$ Bravo EL, Tarazi RC. Converting enzyme inhibition with an orally active compound in hypertensive man. Hypertension 1979;1:39-46.

${ }^{13}$ Gavras H, Brunner HR, Turini GA, et al. Antihypertensive effect of the oral angiotensin converting-enzyme inhibitor SQ 14,225 in man. $N$ Engl f Med 1978;298:991-5.

14 Atlas SA, Case DB, Sealey JE, Laragh JH, McKinstry DN. Interruption of the renin-angiotensin system in hypertensive patients by captopril induces sustained reduction in aldosterone secretion, potassium retention and natriuresis. Hypertension 1979;1 :274-80.

${ }^{15}$ MacGregor GA, Markandu ND, Roulston JE, Jones JC. Essential hypertension: effect of an oral inhibitor of angiotensin-converting enzyme. Br Med f 1979;ii:1106-9.

${ }^{16}$ Case DB, Atlas SA, Laragh JH, Sealey JE, Sullivan PA, McKinstry DN. Clinical experience with blockade of the renin-angiotensin-aldosterone system by an oral converting-enzyme inhibitor (SQ 14,225, captopril) in hypertensive patients. Prog Cardiovasc Dis 1978;21:195-206.

17 Brunner HR, Gavras H, Waeber B, et al. Oral angiotensin-converting enzyme inhibitor in long-term treatment of hypertensive patients. Ann Intern Med 1979;90:19-23.

18 Tree M, Morton JJ. Captopril lowers blood pressure by an additional mechanism independent of angiotensin II. Clin Sci 1980;58:2p.

${ }^{19}$ Man in 't Veld AJ, Schicht IM, Derkx FHM, De Bruyn JHB, Schalekamp MAD. Effects of an angiotensin-converting enzyme inhibitor (captopril) on blood pressure in anephric subjects. Br Med f 1980;280 288-90.

${ }^{20}$ Leslie BR, Case DB, Sullivan JF, Vaughan ED. Absence of blood-pressure lowering effect of captopril in anephric patients. $\mathrm{Br} \mathrm{Med} \mathcal{F} 1980 ; \mathbf{2 8 0}$ : 1067-8.

21 Erdös EG. Angiotensin I converting enzyme. Circ Res 1975;36:247-55.

${ }^{22} \mathrm{McCaa}$ RE, Hall JE, McCaa CS. The effects of angiotensin I-converting enzyme inhibitors on arterial blood pressure and urinary sodium excretion: role of the renal renin-angiotensin and kallikrein-kinin systems. Circ Res 1978;43, suppl 1:32-9.

${ }^{23}$ Swartz SL, Williams GH, Hollenberg NK, Levine L, Dluhy RG, Moore TJ. Captopril-induced changes in prostaglandin production: relationship to vascular responses in normal man. $\mathcal{F}$ Clin Invest 1980;65:1257-64.

${ }^{24}$ White NJ, Yahayi H, Rajagopalan B, Ledingham JGG. Captopril and frusemide in severe treatment-resistant hypertension. Lancet 1980; ii: $108-10$.

${ }^{25}$ Atkinson AB, Brown JJ, Fraser R, et al. Antagonists and inhibitors of the renin-angiotensin-aldosterone system in the treatment of hypertension. In: Robertson JIS, Pickering GW, eds. The therapeutics of hypertension. London: Academic Press, 1980:29-61.
${ }^{26}$ Grossman A, Eckland D, Price P, Edwards CRW. Captopril: reversible renal failure with severe hyperkalaemia. Lancet $1980 ; \mathrm{i}: 712$.

${ }^{27}$ Aurell M, Rudin A, Tisell L-E, Kindblom LG, Sandberg G. Captopril effect on hypertension in patient with renin-producing tumour. Lancet 1979 ;ii:149-50.

${ }^{28}$ Vaughan ED, Carey RM, Ayers CR, Peach MJ. Hemodialysis-resistant hypertension: control with an orally active inhibitor of angiotensinconverting enzyme. 7 Clin Endocrinol Metab 1979;48:869-71.

${ }^{29} \mathrm{McCaa}$ CS, Langford HG, Cushman WC, and McCaa RE. Response of arterial blood pressure, plasma renin activity and plasma aldosterone concentration to long-term administration of captopril in patients with severe, treatment-resistant malignant hypertension. Clin Sci 1979;57: $371 \mathrm{~s}-3 \mathrm{~s}$.

${ }^{30}$ Lopez-Ovejero JA, Saal SD, D'Angelo WA, Cheigh JS, Stenzel KH, Laragh JH. Reversal of vascular and renal crises of scleroderma by oral angiotensin-converting-enzyme blockade. $N$ Engl f Med 1979;300: 1417-9.

${ }^{31}$ Leonetti G, Terzoli L, Sala C, Bianchini C, Sernesi L, Zanchetti A. Relationship between the hypotensive and renin-stimulating actions of diuretic therapy in hypertensive patients. Clin Sci Mol Med 1978;55: $307 \mathrm{~s}-9 \mathrm{~s}$.

32 Ibsen H, Leth A, Hollnagel H, Kappelgaard AM, Nielsen MD, Giese J. Renin-angiotensin system in mild essential hypertension. The functional significance of angiotensin II in untreated and thiazide-treated hypertensive patients. Clin Sci Mol Med 1978;55:319s-21s.

${ }^{33}$ Atkinson AB, Brown JJ, Lever AF, Robertson JIS. Combined treatment with captopril and diuretic in severe intractable hypertension. Lancet 1980 ;ii: $105-8$.

34 Vlasses PH, Ferguson RK. Temporary ageusia related to captopril. Lancet $1979 ; \mathrm{ii}: 526$.

${ }^{35}$ Seedat YK. Aphthous ulcers of mouth from captopril. Lancet 1979 ;ii: 1297-8.

${ }^{36}$ Van Brummelen $P$, Willemze R, Tan WD, Thomson J. Captoprilassociated agranulocytosis. Lancet $1980 ; \mathrm{i}: 150$.

37 Amann FW, Bühler FR, Conen D, Brunner F, Ritz R, Speck B. Captoprilassociated agranulocytosis. Lancet $1980 ; \mathrm{i}: 150$.

${ }^{38}$ Hoorntje SJ, Weening JJ, Kallenberg CGM, Prins EJL, Donker ABJM. Serum-sickness-like syndrome with membranous glomerulopathy in patients on captopril. Lancet 1979 ;ii $: 1297$.

${ }^{39}$ Prins EJL, Hoorntje SJ, Weening JJ, Donker ABJM. Nephrotic syndrome in patient on captopril. Lancet 1979 ;ii:306-7.

${ }^{40}$ Hoorntje SJ, Kallenberg CGM, Weening JJ, Donker ABJM, The TH, Hoedemaeker PJ. Immune-complex glomerulopathy in patients treated with captopril. Lancet $1980 ; \mathrm{i}: 1212-5$.

${ }^{41}$ Atkinson AB, Brown JJ, Lever AF, et al. Neurological dysfunction in 2 patients receiving treatment with captopril and cimetidine. Lancet 1980 ;ii :36-7.

42 Jorizzo JL, Sams WM, Jegasothy BV, Olansky AJ. Cimetidine as an immunomodulator: chronic mucocutaneous candidiasis as a model. Ann Intern Med 1980;92:192-5.

${ }^{43}$ Devine BL, Fife R, Trust PM. Minoxidil for severe hypertension after failure of other hypotensive drugs. $B r$ Med $\mathcal{f} 1977$;ii:667-9.

\section{Prevention or cure for stress-induced gastrointestinal bleeding?}

Patients who are seriously ill, from whatever cause, are prone to develop acute upper gastrointestinal bleeding-a problem that is growing as more such patients are treated in intensive care units. The most severely ill patients are at particular risk: one study ${ }^{1}$ in an intensive care unit found massive bleeding only in patients with combinations of several serious complications, including respiratory failure, hypotension, sepsis, and jaundice. Bleeding in these patients is usually due to gastritis and acute gastric ulceration, ${ }^{2} 3$ though oesophageal and duodenal lesions may also occur. The pathogenesis of these lesions is incompletely understood. Factors that might be important include gastric acid, ${ }^{4}$ bile salts, ${ }^{5}$ the secretory state of the gastric mucosa, ${ }^{6}$ blood flow in the gastric mucosa, ${ }^{5}$ malnutrition, ${ }^{7}$ drug treatment, and coagulation defects.

In experiments on animals gastric acid seems to be essential for the development of these lesions, ${ }^{568}$ and they can be 